\title{
How Do They Think Differently?: A Social Media Advertising Attitude Survey on Chinese Students in China and Chinese Students in America
}

Anan Wan

West Virginia University

Follow this and additional works at: https://researchrepository.wvu.edu/etd

\section{Recommended Citation}

Wan, Anan, "How Do They Think Differently?: A Social Media Advertising Attitude Survey on Chinese Students in China and Chinese Students in America" (2013). Graduate Theses, Dissertations, and Problem Reports. 263.

https://researchrepository.wvu.edu/etd/263

This Thesis is protected by copyright and/or related rights. It has been brought to you by the The Research Repository @ WVU with permission from the rights-holder(s). You are free to use this Thesis in any way that is permitted by the copyright and related rights legislation that applies to your use. For other uses you must obtain permission from the rights-holder(s) directly, unless additional rights are indicated by a Creative Commons license in the record and/ or on the work itself. This Thesis has been accepted for inclusion in WVU Graduate Theses, Dissertations, and Problem Reports collection by an authorized administrator of The Research Repository @ WVU. For more information, please contact researchrepository@mail.wvu.edu. 
How Do They Think Differently?: A Social Media Advertising Attitude Survey on Chinese Students in China and Chinese Students in America

\author{
Anan Wan \\ Thesis submitted to the \\ Perley Isaac Reed School of Journalism \\ at West Virginia University \\ in partial fulfillment of the requirements \\ for the degree of
}

Master of Science in

Journalism

Rita F. Colistra, Ph.D., Chair
R. Ivan Pinnell, Ph. D.
Elizabeth Oppe, Ph. D.
Nicholas D. Bowman, Ph. D.
Department of Journalism

Morgantown, West Virginia

2013

Keywords: Social Media; Advertising; Chinese students in America; Social media diet

Copyright 2013 Anan Wan 


\title{
ABSTRACT \\ How Do They Think Differently?: A Social Media Advertising Attitude Survey onChinese Students in China and Chinese Students in America
}

\begin{abstract}
Anan Wan
This study explored whether Chinese students in both China and in America had different attitudes toward social media advertising, and how their attitudes are different, through a survey of Chinese students in these two countries. The survey determined how they used social media, whether the different social media networks in the two countries affected their social media use, and what their attitudes are about social media advertising in terms of sources, content, and level of trustworthiness. It also tested the relationship between the students' the social media diet (amount, frequency, and duration) and attitude toward social media advertising.
\end{abstract}




\section{Table of Contents}

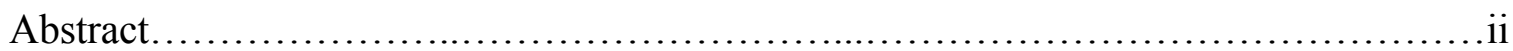

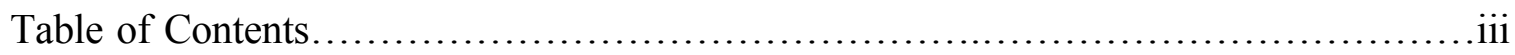

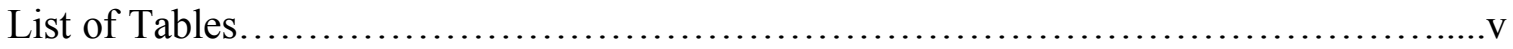

Chapter 1: Introduction.......................................................

Chapter 2: Literature Review................................................ 3

Chinese Social Media vs. American Social Media.................................

Chinese College Students Using Social Media..................................4

Social Media Advertising in China and in America.................................................5

Unethical Social Media Advertising Behaviors in China and in America...............8

Social Media Diet....................................................... 10

Chapter 3: Research Questions and Hypotheses................................... 12

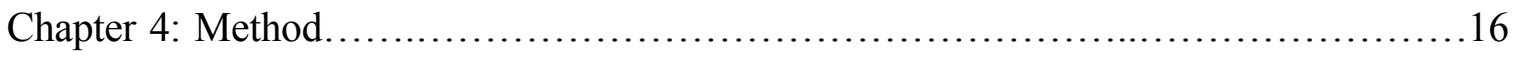

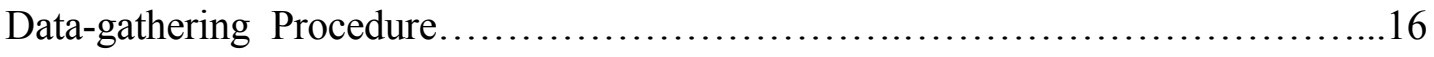

Sample................................................................. 16

Survey Instrument.................................................. 17

Participants............................................................ 19

Measures.............................................................20

Chapter 5: Results........................................................ 22

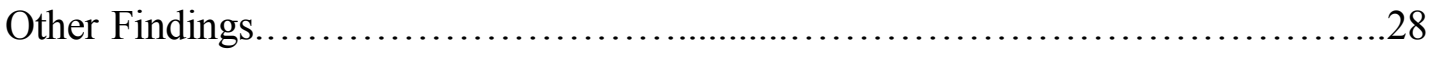

Chapter 6: Discussion.................................................... 30

Limitations and Future Directions........................................ 34 
Chapter 7: Conclusion.................................................... 36

Appendices.............................................................. 37

Screenshot of Renren-Chinese Version of Facebook.............................. 37

Screenshot of Weibo-Chinese Version of Twitter............................... 38

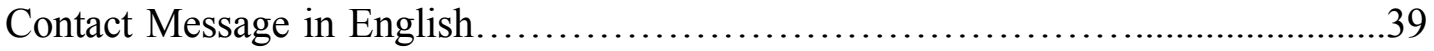

Contact Message in Chinese.............................................40

Consent Form in English................................................41

Consent Form in Chinese...............................................43

Survey Questions in English........................................45

Survey Questions in Chinese..............................................52

IRB Approval Letter.................................................59

Confirm Letter of Translation................................................6

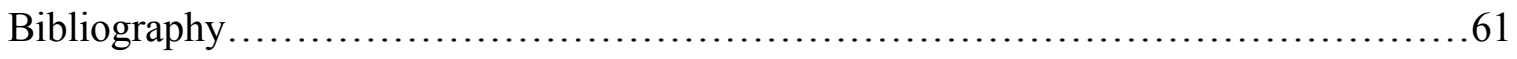




\section{List of Tables}

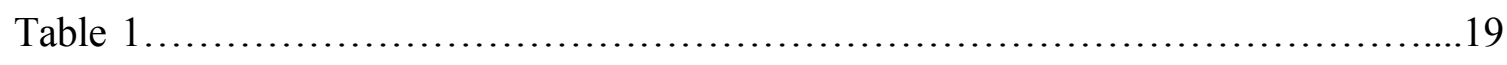

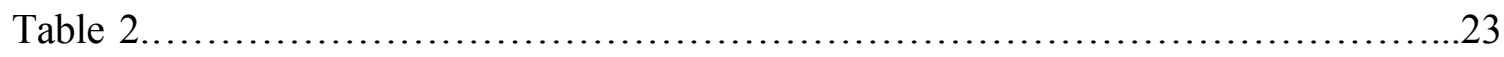

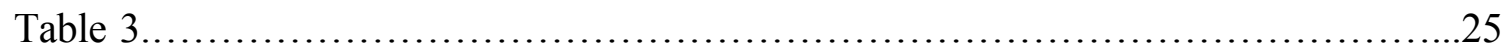

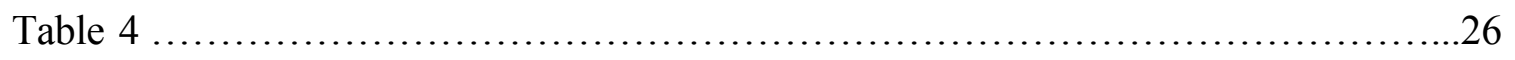




\section{Chapter 1: Introduction}

This paper introduces the Chinese-based social networking sites (SNS), Renren (see Appendix 1) — the Chinese version of Facebook — and Weibo (see Appendix 2) — the Chinese version of Twitter - and the different advertising methods used on these SNS. Because of the Chinese "Great Firewall," internationally used SNS have been banned in Mainland China since 2009 (Hassid, 2008). As a result, Chinese students have been using their own versions of SNS. With the rapid development of the Chinese social networks, advertising on these social networks has become an important and creative branch of the Chinese advertising industry. As the number of Chinese international students studying in America grows, these students are able to use two different kinds of SNS, both Chineseand U.S.- based. It is surprising that there has been little to no research related to how Chinese international students in America use these social media and what they think about them.

Previous research about Chinese college students in China's social media use (Cao, 2012), characteristics of Chinese social media advertising (Fong, 2011), college students' views about advertising on social networks (Han \& Ji, 2012) can be easily found. However, there are few studies about how social media advertising can be more effective on college students, which is especially important because they are the main users of SNS in China (Shim, 2011).

In order to attract a larger target audience and pursue higher profits, unethical behavior in social media advertising also exists in both China and in America, according to recent reports (Burns, 2008 \& Zong, 2010). These behaviors include posting fake customer reviews and experiences by advertising companies. Thus, it is another issue 
that should be considered. Whether both groups of students are aware of this phenomenon is still unknown.

The purpose of this study is to examine these two groups of Chinese students' (those in China and those in America) attitudes toward social media advertising. Due to the differences between these two popular social networks - Chinese-based and American- based — the advertising methods being used on these social media are also different. Chinese students in America are the main group that is able to experience the differences, as Chinese students in Mainland China are not allowed to use American SNS. Specifically, this research will explore the social media use and the attitudes about SNS advertising of these two groups of students using a survey of Chinese college students.

This study will help to advance the current knowledge base about social media advertising among these groups. It will enable social media advertisers to better understand their target audience, both Chinese students in China and in America, and to develop improved methods of getting their messages to these audiences. 


\section{Chapter 2: Literature Review}

Chinese Social Media vs. American Social Media

To better understand Chinese social media and how the advertising applies to it, the features of the Chinese social media are examined. To keep Chinese people off of foreign websites, the Chinese government uses electronic barriers - the "Great Firewall"- to keep Mainland China a "safe" Internet environment. Healy (2007) discusses how government involvement in the Internet in China and Chinese Internet users are blocked from the foreign websites including the social networking websites, such as Facebook, Twitter, and YouTube.

The "Great Firewall" offers Chinese companies that closely resemble the American social media companies a great opportunity to grow in a large market, which will have an estimated 500 million Internet users by the end of 2012 (Healy, 2007). As Xiao (2011) points out, Chinese research asserts that with American-created and internationally-used social media brands like Facebook, Twitter, and YouTube blocked, more than 210 million Chinese Internet users use their own versions of social networking websites (Xiao, 2011). This unique feature of the Chinese Internet scheme makes studying Chinese social media and its advertising significant to the entire world market.

In America, online social networks like Facebook, YouTube, and Twitter have been popular long before the Chinese versions were developed. Although the networks and Internet environments Chinese SNS and American SNS are quite different due to the government regulations, they still share the same features. Smith (2009) argues that social media have redefined the way the Internet functions because these social media sites allow Internet users to publish opinions, connect, build community, or produce and 
share content. Everyone from anywhere, even if the people who are not actively involved in social media, can feel the revolution social media brought to society.

\section{Chinese College Students Using Social Media}

According to Cao's (2012) social media use survey of college students in the university town of Fuzhou in 2012, 79 percent of college students use social media about 14 hours per day. The survey finds that these main users of Chinese social networks prefer to express personal feelings, interact with friends, and get information from social media, much like their U.S. counterparts.

According to Ouyang (2012), College students in China are freer and more active than other Chinese traditional media audiences. He finds that using social networks to get information and communicate with others requires social media users to have the abilities to choose, understand, criticize, evaluate, and produce information. Although the Internet is not as widely used in China as it is in America, college students in China are the main users of Internet and social media. Also, with the popularity of smart phones and the development of the apps, everyone is able to use social media almost anywhere and whenever they want.

Fake or misleading information forces college students to determine the value of every piece of information they get from social media, according to Zhao \& Wu (2012). College students with less social experience and fewer rational thoughts are more likely to be misled by fake information on social media than other social media users.

Han and Ji's (2012) interviews of Chinese college students found that this group knows less about business information from social media than the information about 
news, entertainment, business, and reference information. For the business and advertising information they get from social media, 88 percent of the interviewees think the resources of the information are the most important factor in determining the reliability of the information. They are also are only concerned with the advertisement and business information that involved them most, which is the same for the traditional news.

In October 2010, Shim (2011) conducted a survey about understanding social media advertising on college students in China and in South Korea. Findings indicate that both Korean and Chinese college students have noticed the existence of the misleading and fake information on Chinese social media. Moreover, he finds that Chinese college students care most about the content and the creativity of the advertisements on social media, and they want to see more trustworthy advertisements.

\section{Social Media Advertising in China and in America}

Viner (2007) demonstrates how the H.R. 4780, the Global Online Freedom Act of 2006, would be an effective piece of legislation to hold U.S. Internet companies accountable for user-rights violations while maximizing users' digital access. The article presents China as an example of an Internet-restricting country, where Internet users' right to freedom of expression is in conflict with the economic realities of Chinese market and U.S. business interests. He suggests that the "Great Firewall" of China and China's unique Internet media environment means Chinese social media users have less access to universally used social networking websites like Facebook, and Twitter.

Renren, the Chinese version of Facebook, has the largest market share and 
advertising income among Chinese social media (Fong, 2011). Until February 2012, 130,565 enterprises had official Weibo (Chinese version of Twitter) accounts to promote their services and products for branding and marketing purposes (An, 2012). According to An's research on college social media users in Shanghai, the respondents prefer to share their purchasing experiences and make comments on companies' Weibos. Also, when they have problems with the product or service they purchased, they would first turn to the brands' official Weibo accounts for help.

Fong (2011) asserts that first, in the start-up stage of an SNS service company, it engages in product development to obtain funding resources and market so as to enhance market share. Second, in the growth stage of SNS service, the SNS company engages in product financing through the capital market and trade financing. The most traditional means of soft advertising on Renren is the same as Facebook - the feature "like." Users can like a public page, which may be a celebrity, a fabricated person, a company, a university, and more. Once a user has liked a page, updates from that page show up in his/her Facebook news stream where his/her friends can see it, too- an important hook for viral marketing, according to Fong (2011). That is to say, if one user, who has 1,000 friends on Facebook, "likes" this product or brand, it can be spread to another 1,000 potential customers. Then if any of these 1,000 friends liked the page again, it can reach all of his/her friends. The whole process presents a snowball effect to advertise for free.

Although these social media are the Chinese versions of their American counterparts (Facebook and Twitter), there are still some advantages and new functions that make the advertising methods quite different from American advertising. Besides, the functions 
"share" and "like" in Renren are much different from its original version, Facebook. For example, Renren users can share everything including photos, videos, and blogs (Renren has the function of posting blogs) from Renren or outside Renren. There is also a service called "Renren Palace," which ranks the most shared photo albums, articles, and videos (Fong, 2011). Once the photo, blog post, or video includes a brand or product being ranked in Renren Palace, it means it has been reached by a large audience. Viner (2007) asserts that it will be difficult for original American social media companies to enter the Chinese market because the existing Chinese SNS fit the Chinese market better than American SNS. It illustrates that besides the help of the "Great Firewall," the special functions that is provided by Chinese social network companies help them to gain a larger market share.

Social media advertising can be divided into two groups: direct advertising and indirect advertising. Direct advertising includes the sponsorship links on the left side of the website page, advertisements on the login page and the top of the homepage, and the public pages of the brands, products, and companies. Indirect advertising consists of public pages of celebrities, passages, pictures and videos shared by users, comments, and messages.

Hassid (2008) contended that direct advertising is the main revenue stream of Renren, followed by Nuomi.com, a Groupon-type service layered on top of the social network, and Renren Games that operates casual and MMORPGs on the Renren platform and elsewhere. According to Yang (2009), using viral marketing strategy on SNS depends more on the SNS users' personal influences and credibility rather than other regular marketing strategies because one's Facebook or Twitter can identify what he/she looks like and how 
he/she appears to others through SNS. This strategy requires advertisers and marketers to change their methods of advertising on SNS. Yang asserts that although SNS users spend a considerable amount of time on social media, they seldom click or care about advertisements on these sites. That is to say, most social media users are not impressed by the advertisements on it. Social media advertisements cannot be fully used without being distributed to different target groups specifically, as social media users seem to only pay attention to those advertisements that matter to them.

\section{Unethical Social Media Advertising Behaviors in China and in America}

There are some questionable advertising methods used by some advertising companies in both China and in America. These potentially unethical practices are a bigger problem in China than in America in terms of the degree and instances of occurrence. Thus, Chinese audiences react more than American audience on this issue, which causes strong discussions in Mainland China (Zong, 2010).

In China, these advertising companies are called "Internet promotion" companies. The Internet marketers hire a large number of people who can get 50 cents for writing a comment or for sharing an article for their products on social media with the hopes of changing public opinion. Internet Water Army is "a group of Internet ghostwriters paid to post online comments with particular content" ("Internet Water Army," n.d.). The private Internet Water Army operations parallel the " 50 Cent Party" - the Internet commentators hired by the Chinese government to post comments favorable toward party policies in an attempt to shape and sway public opinion. "Water Army" refers to the large number of people who are well organized to "flood" the Internet with purposeful comments and 
articles. "Water" also means something is impure and fake, rather than the liquid that people drink. Members of the "50 Cent Party," are paid 50 cents to comment once (Zong, 2010).

On the Chinese Twitter site, Weibo, the people hired by the Internet promotion companies to follow the microblog users are called "zombies," which is from a new Water Army title reported by Xinhua News Agency. Zhang (2011) explained that "zombies" are artificial followers that can be bought and sold online for as little as four yuan (63 cents). Zombies never "interact with the people they follow, but they serve the vanity of micro- bloggers, inflate the accounts of businesses that rely on marketing through social media, and can jeopardize a company's reputation” (Zhang, 2011, para. 4).

These viewers post spam to the original articles to help raise these articles to the top of the whole social media website. Zong (2010) concluded the reasons for the increasing of "Internet Water Party" are the information technology boom, the drive of economic interests, the improvement of Internet marketing and PR, and people's special social \& psychological environment in a social transition period.

"Wal-Marting Across America" is a blog campaign sponsored by the working families for Wal-Mart, a group created by Wal-Mart Stores' public relations firm, Edelman. From Burns' (2008) case study of this blog campaign, he stated that "WalMarting across America" represents a new media ethics crisis, which started with a blog. Blogs, as one of the mainstream platforms of social media, lack transparency, and transparency is one of the major ethical issues for marketing, advertising, and public relations practitioners who create blogs for publicity and advertising.

Based on research of La Ferle, Edwards, \& Lee (2008), the differences between 
Chinese and American consumers on their attitudes toward advertising and media-use patterns are significant. This article examined cultural orientations, attitudes toward advertising, and media-use patterns across China, Taiwan, and the United States. China and Taiwan share similar cultural backgrounds, but compared to United States, their economies and advertising industries have evolved quite differently due to different social and political settings. They suggest that Chinese consumers were less individualistic and more collectivistic than their counterparts in the U.S., and they also exhibited more favorable attitudes toward advertising than American consumers. Furthermore, Chinese respondents spent significantly more time with print media than American respondents. However, this research was about the opinions on general advertising and the overall Chinese population before the high development of Chinese social media advertising. The opinion toward social media advertising of Chinese college students might be different due, in part, to the unethical behaviors of "Water Army" and "Zombie followers".

\section{Social Media Diet}

Media diet refers to how media audiences choose, interpret, and interact with the mass media, according to Brown (2000). Roberts (2000) described the U.S. youth's access and exposure to the full array of media through using TV, videotapes, movies, Internet, and newspapers, as well as the through social contexts in which media exposure occurs. Their access to these media, the time they spend, and the media contents they receive all consists of their media diets.

In the Internet era, Johnson (2012) asserts that media users become gluttons for texts, instant messages, emails, RSS feeds, downloads, videos, status updates, and tweets, 
spending upwards of 11 hours out of every 24 in a state of constant consumption. Based on his theory of information "diet," media uses are able to learn how to thrive in this information glut — what to look for, what to avoid, and how to be selective. In the process, Johnson (2012) explains the role information has played throughout history, and why the information diet is essential for media users who strive to be smart, productive, and sane.

Thus, different social media diets of different SNS users can be one of the factors that might determine how much and how long they can be reached by the advertisements on social media. Furthermore, all these factors might affect their attitude of social media advertising.

According to all these previous studies, Chinese students in China and those in America uses different SNS due to the different networks that are available in these two countries. This might cause the two groups of Chinese students to have different social media diets. The different degrees of unethical social media advertising behaviors in these two countries might also cause their attitude toward social media advertising to differ. However, research about how Chinese college students think about social media advertising is limited, and the comparison between the attitudes of the Chinese students in China and in America has rarely been made. Researches about their attitudes will help international advertisers better understand these groups' views of social media advertising. 


\section{Chapter 3: Research Questions and Hypotheses}

The "Great Firewall" of China makes Chinese college students in China use the different network from the students in America, as well as the SNS that are available for them. Although the existence of the "break-wall" software might allow Chinese student be able to use American SNS (Facebook and Twitter), the actual number of students who use the software is unknown, as is their physical use of SNS. Using different networks might affect these two groups of students' attitudes toward social media advertising. Chinese students in China might have more negative attitudes than Chinese students in America due to the different degrees of unethical advertising behaviors on social media. The social media diets may also affect their attitudes as well. Longer and more frequent use of social media might make their attitudes toward social media advertising stronger. Based on the information derived from the literature review, the following hypotheses are proposed.

H1: Chinese students in America physically use more SNS than Chinese students in

\section{China.}

Due to the "Great Firewall" of China and the control policy of Chinese government, Chinese social media users will have less access to social networking sites compared to those who are in America. However, the "break-wall" software enables Chinese users, especially the Chinese college students, to freely surf the banned foreign social networking websites. But the amount of these "break-wall" software users is unknown, as is the social media access of Chinese students in these two countries. Therefore, the physical use, means the "actual use" (combination of amount, duration, and frequency), of SNS in China is hypothesized to be less than in America. 
RQ1: Does Chinese students' social media diet affect their attitude toward social media advertising?

The social media diet is indicated by how often they use social media per week (frequency), how many years they have used social media (duration), and how many times they check their SNS accounts per day (amount). Thus, different social media might affect students' opinion of the advertisements on social media. Social media users who use more (the combination of frequency, duration, and amount) social media might have stronger attitudes than those who use less social media. That is to say, whether both groups of Chinese students who using more social media might make their attitudes toward social media advertising stronger than using less social media is unknown.

H2: Different social media networks of China and America make Chinese students in China had a more negative social media advertising attitude than Chinese students in America, while Chinese students in America hold a more positive attitude than Chinese students in China.

Because of the "Great Firewall" of China, Chinese college students in China use a different network, also the social media network, than the network Chinese students use in America. With more occurrences of unethical social media advertising in Chinese social media, such as Water Army and Zombie followers, Chinese social media advertising is considered as less credible compared with the TV advertising (Zong, 2010). The attitude toward social media advertising of Chinese students in China might be more negative than that of Chinese students in America. Whether the different networks they use will affect the attitudes of these Chinese students is still unknown. Thus, the following hypothesis is proposed. 
RQ2: Do Chinese Students in China consider social media advertising as less trustworthy than Chinese students in America?

Although La Ferle, Edward \& Lee's research in 2008 suggested that the general Chinese population trusted advertising more and had more favorable opinions, the specialty of Chinese control of social media use and the unethical advertising behavior on social media in China make the credibility of its advertising different than advertising on other media outlets. Chinese social media advertising might be considered as less authentic and less reliable in terms of their recognition of fake advertising and unethical social media advertising, the trustworthiness of social media advertising compared to that on traditional media, and the advertisements' contents and sources than in the US. Therefore, Chinese college students' attitude toward advertisements on social media should be tested. 


\section{Chapter 4: Method}

The attitudes of Chinese college students in China and in America toward social media advertising and their social media diets were examined through a survey of Chinese college students in both countries. The following paragraphs introduce the data- gathering process, sample, survey instrument, participants, and measures.

\section{Data-gathering Procedure}

Data were obtained through a web-based survey of Chinese students who are studying in both China and America. Because of monetary and time constraints, the survey was distributed through the "message" function on SNS (Facebook or Twitter for students in America; Renren or Weibo for students in China). Doing so also ensured that all survey participants were social media users.

Survey Monkey was used to execute the survey. This survey software allowed responses to be automatically recorded and analyzed. A website link of the survey was sent to the first participants on SNS. Every participant could take the survey anywhere and anytime, which made the survey convenient for participants.

\section{Sample}

Snowball sampling was used to identify participants for the survey because, according to Zhou \& Sloan (2011), it was an effective method to use "when individuals with certain characteristics of interest are hard to locate" (p. 148). To begin the snowball process, the first 50 participants selected by the researcher in each country were asked to introduce the survey to another 5 potential participants sharing the same 
characteristics. These additional participants would also be asked to recruit other similar members to include in the sample.

This was considered a convenience sample because the survey was simply promoted on SNS. It was necessary to use these methods because a reliable sampling frame containing the names and contact information for these groups would be difficult to find. Therefore, a random sample was not possible because of time constraints and available resources.

\section{Survey Instrument}

As previously mentioned, this study used a web survey (see Appendix 7: Survey Questions in English) to obtain participant responses. An online survey was able to be accessed by a large number of respondents at one time at much lower costs than with other survey data collection methods (Zhou \& Sloan, 2011).

A contact message (see Appendix 3: Contact Message in English) was sent through the "message" function on Facebook, Weibo, and Renren to each participant on March 11, 2013. It included a brief introduction of the researcher and the survey, the website link to the survey's consent letter (see Appendix 5: Consent Form in English), and the survey. By clicking the "consent" on the consent page, participants would be directed to the survey questions.

A week after the contact message was sent, the same contact message was sent again to the non-responders. The survey was closed on April 1, 2013, which was three weeks after the first contact message was sent.

The consent message and consent form were developed from Brown (2011) and 
Colistra (2008), and presented with official West Virginia University Perley Isaac Reed School of Journalism letterhead and footer.

The contact message, consent form, and the survey were all in Chinese, as Chinese was the survey participants' native language, which allowed participants to better understand and provide more straightforward answers. The English versions were translated by the researcher, and the translation was confirmed as accurate and appropriate by Dr. Hannah Lin, the Chinese Studies Program Director at West Virginia University (see Appendix 10: Confirm Letter of Translation). The Institutional Review Board (IRB) at West Virginia University acknowledged approval of this research, survey, and all the communications with participants.

The questionnaire for the survey included 23 questions consisting of three parts: basic demographic information, social media diet (amount, frequency and duration), and opinions about social media advertising. The survey consisted of yes/no, check which best applies, and 5-point Likert-type scale questions, as well as an additional comment box. Table 1 shows which research question or hypothesis corresponds with each survey question. 
Table 1: Link between Research and Survey Questions

Hypotheses and Research Questions

Survey Questions

RQ1: Does Chinese students' social media diet affect

$4,6,7,8,16,20,21,22$, 23

their attitude toward social media advertising?

RQ2: Do Chinese Students in China consider social media advertising as less trustworthy than Chinese students in

$4,5,6,7,8,10,11,12$ America?

H1: Chinese students in America physically use more SNS than Chinese students in China.

H2: Different social media networks of China and America make Chinese students in China had a more negative social media advertising attitude than Chinese students in America, while

Chinese students in America hold a more positive attitude than Chinese students in China.

Social Media Diet

$4,6,7,8$

$4,15,16,21,22$

$4,5,6,7,8$

\section{Participants}

As mentioned previously, 50 participants in each country were contacted, then the survey was sent to another 5 participants by each initial participant. A total of 317 people started the survey, but 252 participants completed all questions. Thus, the percentages reported in this study are based on the latter 252 respondents. Of the useable sample, $35.7 \%$ (90) were from the students who had US education experience, and $64.3 \%$ (162) from the students who went to college in China. Participants' average age was 24.9, with $44.4 \%$ (112) males and 55.6\% (140) females. The majority of participants were in the 2429 age group (52\%), followed by the $18-23$ age group (38\%) 


\section{Measures}

Four questions were used to obtain the necessary demographic information.

Questions about age, gender, and educational status were asked not only to provide a description of the participants, but to also ensure that each participant was a valid fit for the project (i.e., Chinese college students who are either studying in China or America). Then, another question about whether they have/had US education experience was also included.

The social media diet portion of the survey asked questions about how many years they have been using social media, how many times they check social media per day, and how many days they use social media per week. According to Bowman (2012), to assess respondent's overall media diet, an adapted version of the "Kreek-McHughKellogg” (2003) substance usage scale was used. This scale measured one's frequency (" $0=$ not at all" to " $4=7$ days"), amount (" $0=$ not at all" to " $4=$ more than 20 times per day") and duration (" $0=$ not at all" to " $4=5$ or more years") of social media, creating a summed composite measure from 'three one-item sub-dimensions ranging from ' 0 ' (virtually no use) to '12' (frequently, daily, and long-term user)" (Bowman, 2012).

A 5-point scale Likert-type question of how often they used Facebook or Twitter was included to test the American SNS use of participants in America or the "breakwall" software use of participants in China. Six yes/no questions were asked to examine participants' recognition of social media advertising, fake advertising, and the unethical advertising behaviors on social media.

The last part had 10 5-point scale Likert-type questions to examine the participants' opinions about social media advertising. Opinions about the trustworthiness of content 
and sources of social media advertisements, how advertisements on social media affected their purchasing behaviors, and the general attitude of social media advertising compared to advertising on traditional media were examined.

An open-ended "additional comment" box was added at the end of the survey. The comment box was optional to answer. Although the information was not included in the data-analysis, some additional comments could be pulled out to use in the discussion to elaborate on some points found in the survey results.

The survey was pretested on 10 Chinese students, 5 studying in China and 5 studying in America, who were not included in the final sample. The pretest was used to determine the amount of time taken to complete the survey and to adjust question wording, if necessary. According to the pretest, the survey could be finished within six minutes. It was also found that it might be difficult for participants to thoroughly understand terms and definitions. Thus, definitions of some terms were included in the survey to help participants answering the questions without misunderstandings. 


\section{Chapter 5: Results}

The purpose of this study was to examine whether Chinese students in China and Chinese students in America had different attitudes toward advertisements on social media and if so, what caused these differences. Questions about how they used social networks differently and their opinions about advertisements on different SNS in each country were asked to test whether different networks they used caused their different attitudes toward the advertisements on social media. An adapted version of "KreekMcHugh-Schluger-Kellogg substance usage scale" was used to evaluate the social media diets (combination of frequency, amount, and duration) of them. The relationship between social media diet of students in both countries and their opinions toward advertisements on social media was found. The social media diet also provided a basis in evaluating and comparing the actual use of SNS of the students in each country.

\section{H1: Chinese students in America physically use more SNS than Chinese students in}

\section{China.}

The physical use of social media means the amount, duration, and frequency of how both groups of Chinese students use social media in different networks. Based on the adapted "Kreek-McHugh-Kellogg” (2003) substance usage scale, there are three questions about how many years they have used social media, how many times they check social media every day, and how many days they use social media per week. For each question, there were five options, ranging from 0 to 4 points.

As shown in Table 2, the average of all participants' social media diet was 8.71 out of 12. For the Chinese students in America, the average was 8.91, which was 0.30 higher 
than that of Chinese students in China (8.61). Thus, hypothesis 1 was supported.

Table 2: Social Media Diet

\begin{tabular}{|l|l|l|l|}
\hline Social Media Diet Question & \multicolumn{1}{|c|}{ US } & \multicolumn{1}{|c|}{ China } & Total \\
\hline $\begin{array}{l}\text { Q6: How many days do you use social } \\
\text { networks per week? }\end{array}$ & 3.33 & 3.33 & 3.33 \\
\hline $\begin{array}{l}\text { Q7: How often do you check your } \\
\text { social networks per day? }\end{array}$ & 2.08 & 1.77 & 1.88 \\
\hline $\begin{array}{l}\text { Q8: How many years have you been } \\
\text { using social networks? }\end{array}$ & 3.53 & 3.54 & 3.535 \\
\hline Total & $\mathbf{8 . 9 1}$ & $\mathbf{8 . 6 1}$ & $\mathbf{8 . 7 1}$ \\
\hline
\end{tabular}

For different sexes, the average of female participants' social media diet was 8.79 , while it was 8.69 for male participants. Among the total 252 participants, 26 were the heaviest users (the score was 12), while 2 were the lightest users (the score was 0). While, $38.5 \%$ (10) of those heaviest users were male, and 61.5\% (16) were female. A total of 42.3\% (11) heaviest users were the students in America, while 57.7\% (15) of them were students in China.

For question 6 "how many days do you use SNS per week," the averages of all participants' score, that of students in China, and that of students in America were the same - 3.33. The majority (167) of all participants chose "7 days per week." For different sexes, 95 of them were female, and 72 of them were male. Only 6 participants chose "not at all," while 2 of them were female and the remaining 4 were male.

When asked "how often do you check your SNS per day (question 7)," 35 of 252 participants said they checked more than 20 times per day. Among the 35 participants, 21 of them were female, and the remaining 14 were male. Only 5 said 
they never checked SNS, while 1 of them was male. The average score of this question was 1.88. For each country, the average of students in China was 1.77, and 2.08 for students in America.

For question 8 "how many years have you been using SNS," the majority (171) of 252 participants chose "5 or more years." Female participants were 100, which was 29 more than male participants. Only 2 of all participants said they never used SNS, and they were both females. The average score of all participants was 3.54. By country, the average of students in China was 3.54, and 3.53 for students in America.

Findings also showed that only $8.9 \%$ (8) participants in America never used the American SNS (Facebook and Twitter), and a surprising 32.7\% (53) of participants in China used "break-wall software" to log in American SNS. Among the Chinese students in China, 6.8\% (11) of them described themselves as "always" using American SNS. According to results of both participants' social media diets and the frequency of their use of American SNS, Chinese students in America physically use more social media than the Chinese students in China.

RQ1: Do Chinese students' social media diets affect their attitude toward social media advertising?

As previously mentioned, the social media diet of each participant indicated whether he or she was a heavy social media user (frequent, daily, and long-term; the measure was 9 or greater) or a light user (virtually no use; the measure was 3 or fewer). There was an obvious relationship between social media diet and users' attitude toward advertisements on social media, according to the survey results. Among the heavy social media users in 
America, 70\% (63) hold a negative attitude toward advertisements on social media, which was 61.1 percentage points more than those who a hold positive attitude $(8.9 \%$, $\mathrm{n}=8$ ), as shown in Table 3. However, among the light users, there was only a 5.6 percentage-point difference: $10 \%$ had negative attitudes versus $4.4 \%$ positive attitudes (also shown in Table 3).

The same relationship pattern applied to the social media users in China. Refer to Tables $3 \& 4$; a total of $73.5 \%$ of heavy users had negative attitudes toward social media advertising, compared to $22.8 \%$ holding positive views. This finding represents a 50.7 percentage-point difference (illustrated in Table 4). For those Chinese students in China who had a neutral attitude toward social media advertising, the percentage points of light users were 85.8 points more than that of the heavy users, while the percentage points of light users who had a neutral attitude toward social media advertising were 64.5 points more than the that heavy users.

Table 3. Relationship between Social Media Diet and Social Media Advertising Attitude for Chinese Students in America

\begin{tabular}{|c|c|c|c|}
\hline America & Positive + & Negative - & Neutral \\
\hline Heavy users + & $8.9 \%$ & $70 \%$ & $21.1 \%$ \\
\hline Light users - & $4.4 \%$ & $10 \%$ & $85.6 \%$ \\
\hline
\end{tabular}

Table 4. Relationship between Social Media Diet and Social Media Advertising Attitude for Chinese Students in China

\begin{tabular}{|l|c|c|c|}
\hline China & Positive + & Negative - & Neutral \\
\hline Heavy users + & $22.8 \%$ & $73.5 \%$ & $3.7 \%$ \\
\hline Light users - & $4.3 \%$ & $6.2 \%$ & $89.5 \%$ \\
\hline
\end{tabular}


Thus, the more Chinese students used social media, the stronger attitude they would have toward advertisements on social media. It was also easier for heavy users in both countries to define their attitudes toward social media advertising than the light users. That is to say, Chinese students' social media diet affects their attitude toward social media advertising.

\section{H2: Different social media networks of China and America make Chinese} students in China had a more negative social media advertising attitude than Chinese students in America, while Chinese students in America hold a more positive attitude than Chinese students in China.

This hypothesis measured social media attitude by considering their purchasing behaviors and whether they consider advertisements on social media as "annoying" Participants were asked to define how much they were affected by advertisements on social media when making purchase decisions. A total of 64.2\% (104) of Chinese students in China chose "never" or "seldom," which was 1.2\% less than students in America (65.4\%). Only 1.1\% (1) of Chinese students in America chose "always" or "often," while no Chinese student in China considered himself/herself "always" or "often" affected by the advertisements.

When asked about how much they considered advertisements on the social media as "annoying," $67.4 \%$ of students in China and $60 \%$ of students in America chose "often" or "always," and 28.4\% (46) of students in China and 14.4\% (13) of students in America chose "never" or "seldom."

These results suggest that Chinese students in China hold a more negative attitude on social media advertising, as they considered advertisements on social media more 
"annoying." However, they had a less negative attitude toward social media advertising in terms of purchasing the advertised products. For the Chinese students in America, they hold a more positive attitude than Chinese students in China on social media advertising, except for considering advertisements on social media as "annoying." Therefore, the second hypothesis was partially supported.

RQ2: Do Chinese Students in China consider social media advertising as less trustworthy than Chinese students in America?

Trustworthiness of social media advertising was measured by recognition of fake and/or unethical advertising behaviors on social media, trustworthiness of advertisements contents and their sources, and the trustworthiness of advertisements in social media compared to those in traditional media.

A total of 74.1\% (120) of Chinese students in China noticed fake advertisements on Chinese SNS, compared to 63.3\% (57) of Chinese students in America. Among those Chinese students in China (53) who used American SNS, 58.5\% (31) of them "never" or "seldom" noticed fake advertisements on American SNS, compared to 50\% (90) of Chinese students in America who also used American SNS.

At the same time, the percentage of Chinese students in China who noticed unethical advertising behaviors in Chinese SNS (54.3\%) was 3.2 points more than Chinese students in America (51.1\%), and they were able to understand the meanings of Water Army and Zombie followers than students in America. The percentage-point difference between Chinese students in America (11.1\%) who "never" or "seldom" noticed unethical advertising behaviors and those of Chinese students in China (8\%) was 3.1.

No matter where the source of the product reviews came from on social media 
(official accounts, acquaintances, or non-official accounts), students in China ( $M=2.18$, $\mathrm{SD}=1.72)$ did not trust those reviews as much as students in America $(\mathrm{M}=2.49, \mathrm{SD}=1.96)$ did. A total of 74.7\% (121) of students in China and 63.3\% (57) of students in America "never" or "seldom" considered the contents of advertisements on social media as trustworthy; A total of 4.4\% (4) of students in America and 2.5\% (4) of students in China "always" or "often" considered the contents of advertisements on social media as trustworthy.

Compared to advertisements on traditional media (TV, newspapers, or radio), 72.2\% (65) of students in America and 64.8\% (105) of students in China thought advertisements on social media were less trustworthy. Only $11.1 \%$ (10) of students in America believed advertisements on social media were more trustworthy than the advertisements on traditional media (TV, newspapers, or radio), compared to $10.5 \%$ (17) of students in China. Therefore, Chinese Students in China considered social media advertising as less trustworthy than Chinese students in America.

\section{Other Findings}

In order to understand the efficiency of the advertisements on social media, several questions were asked about whether social media users ever paid attention to advertisements on SNS and whether their purchase habits were affected by ads. Question 9 asked whether they noticed the existence of the advertisements on social media. A total of $88.3 \%$ (143) of students in China said "Yes," which was 0.5 percentage point more than students in America $(\mathrm{n}=79,87.8 \%)$. Only $11.7 \%$ of students in China and $12.2 \%$ of students in America stated they never noticed there were any advertisements on social media. 
Several questions were asked about the efficiency of advertisements on social media in terms of participants' purchasing habits. They were "how often do you click advertisement on social media for further information," "how often do you purchase the product that is advertised on social media," and "do you think the advertisements on social media help you to make purchase decision." Only one participant in America chose "always" or "very," while the majority of the participants in both China (64.2\%) and America (65.6\%) held negative opinions toward purchasing products or services that were on social media.

Another notable result from the survey was that participants most trusted product reviews posted by their acquaintances (85), followed by those posted by official accounts (31) and non-official accounts (8). Then, 102, 160, and 200 of all participants "never" or "seldom" trusted product reviews posted by acquaintances, official accounts, and non-official accounts, respectively. 


\section{Chapter 6: Discussion}

This research was to examine whether there were different attitudes toward social media advertising between Chinese students in China and those in America and whether the Chinese students in America change attitudes toward social media advertising after studying abroad. The survey also tested the social media diet of these Chinese-born students according to how many days they used social media per week, how many times they checked social media per day, and how many years they have been using social media by asking questions to examine their different use of social media in two countries due to different networks in each.

These are the 4 main findings:

Finding 1: Chinese students in America physically use more SNS than Chinese students in China.

Although almost one third of Chinese students in China used American SNS that are banned in Mainland China through "Break-wall” software, their average social media score was lower than that of Chinese students in America. That is to say, those Chinese students in Mainland China use American SNSs, but they do not use them as often as Chinese students in America. Students in America physically used more social media than Chinese students in China - in particular, they used their social media accounts more often on a daily basis - due to the more available networks they could use outside Mainland China. Even with the available of "break-wall" software, accessing to the American SNS was not convenient in Mainland China. The social media diet scores of Chinese students in America were higher than those of students in China, but the amount of heaviest social media users in China was greater than that of America. Another notable 
result was that there were still several participants in America not using American SNS, even though both American SNS and Chinese SNS were accessible to them.

Also, female participants used much more than males, whether in China or in America. From their social media diets, females were more than males in terms of frequency, amount, and duration.

Finding 2: Chinese students in China generally had a more negative social media advertising attitude than Chinese students in America, while Chinese students in America hold a more positive attitude than Chinese students in China due to the different SNS they use.

To examine the relationship between different SNS in different countries and Chinese students' attitudes toward advertisements on social media, general attitude and questions were asked concerning fake advertisements and unethical advertising behaviors on social media. More Chinese students in China noticed fake advertisements, unethical advertising behaviors like Water Army and Zombie followers on Chinese social media. On the contrary, less American SNS users in China noticed fake advertisements and unethical advertising behaviors on American social media. Chinese students also found social media advertising to be more annoying than those students studying in America. In general, this finding suggests that Chinese SNSs users in China might be more skeptical of social media advertising as they are more aware of deceptive advertising practices on Chinese SNSs.

How much advertisements on social media affected social media users' purchase habit was another assessment to know their attitude toward social media advertising. The 
majority of all social media users never or seldom purchased advertised products, clicked advertisements, or said that they were affected by advertisements on social media, but more students in America thought they were less affected by those advertisements.

Looking at the open-ended comments adds further support for claims that social media advertising is seen as a rather negative thing overall. From the 18 comments from the optional comment box, 5 (27.8\%) participants mentioned that they considered the advertisements on social media as spam and they hardly paid attention to those advertisements. Another 2 (11.1\%) participants thought the quality of the advertisements was poor. Also, 2 of them said they did not trust the contents of the advertisements on social media and they only trust the advertisements posted by their friends. Only 1 of these comments was made by a Chinese student in America, which might indicate Chinese students in America tended to have less strong feelings than Chinese students in China had. This also showed Chinese students in China had a more negative attitude than Chinese students in America. However, 2 of the participants in China expressed their interests to know more about advertising on social media through their participation in this study, which might suggest that if users knew little about the advertisements on social media even they might use social media very often.

Finding 3: Chinese students' social media diet affects their attitude toward social media advertising regardless of which country they are studying in.

No matter if Chinese students were in China or in America, the more they used social media the stronger and more negative their attitude toward advertisements on social media was. Light users were relatively neutral in terms of their feelings towards social media, while 
heavy users were predominantly negative in their opinions.

Looking at the separate countries, social media users in China were less likely to have neutral opinion, which might be due to the more fake advertisements and unethical advertising behaviors in China than in America, and also the higher prevalence of heavy social media users in China. They were more able to notice and tell those behaviors and advertisements, as their access to the Chinese SNS was more than the Chinese students in America. It was also easier for heavy social media users to define their attitude toward advertisements on social media than light users. Light users who used less social media paid less attention to the advertisements on it, and they did not care about advertisements on social media as heavy users usually did.

Finding 4: Chinese Students in China consider social media advertising as less trustworthy than Chinese students in America

Chinese students in China consider social media advertising less trustworthy than Chinese students in America in terms of advertisements sources and contents - and notably, both groups reported social media advertising to be untrustworthy on the whole. Compared with advertisements on traditional media (newspaper, radio, and TV), advertisements on social media were considered as less trustworthy by Chinese students in America than Chinese students in China. For Chinese students in America, they trusted the sources and contents of advertisements on social media more than Chinese students in China.

Among the product reviews posted by official accounts, acquaintances, and nonofficial accounts on social media, social media users in both countries tended to trust most the reviews posted by acquaintances, then official accounts, and finally the non- 
official accounts. Posting product reviews, as a method of word-of-mouth marketing, were more efficient than advertising alone on social media, as mentioned in one of the comments: "I trusted what my friend wrote about a product on social media". These finding suggest that product recommendations from friends and acquaintances might be useful for advertisers, but on the whole social media advertising was found to be untrustworthy. One reason that we might be skeptical of acquaintances could be the awareness of Zombies and fake users in social media advertising, causing them to question whether the person they are receiving information from really is a "real person."

\section{Limitations and Future Directions}

Chinese students' attitudes changed after they have been studied abroad due to the changes in media environment, more available SNS, and advertisements contents they experienced in America. Understanding media patterns, social media diets and attitudes toward advertising can help better ascertain the potential for using standardized strategies by international advertisers across different markets. Trends affected by the attitudes of college students as the target consumers involving with the social media advertising market can also be monitored.

For advertisers whose target consumers are Chinese college students in both Chinese social media and American social media markets (especially for Chinese advertisers), knowing their attitudes toward their advertisements and their advertising methods will definitely help them broaden their markets and provide more efficient advertisements.

With the increasing numbers of Chinese students studying America and SNS users in China, the characteristics of how Chinese students use social media and their attitude 
toward SNS and advertisements on SNS are essential to find better ways to efficiently advertise on SNS. Research like this one is important to social media advertisers and manufacturers, however this research has several limitations.

This research used a convenience-type of sample, so the results were not able to generalize to populations other than the one it used. The population of Chinese students in Mainland China is huge, and the population of Chinese students in America is hard to locate. Thus, if a random sample can be extracted from these two groups of Chinese students in future research; more exact and useful results would be found and then applied to the social media advertising industry.

The advertisements, whether posted by acquaintances, official accounts, non-official accounts, or the SNS itself, updated very fast, and the contents cover various categories. SNS users' attitude toward these advertisements might change. Also, the social media diet can indicate how social media are used generally, but it is unable to determine whether the social media use is recent or not. Thus, more specific questions should be developed to test the detailed social media use.

Except different networks and different social media diet of Chinese students in both countries, some other aspects might also affect their attitude toward advertisements on social media. Cultural environment, political environment, social environment, and economic environment of each country are totally different. These all may affect the standard of how Chinese students in America view things. Then, questions about how long Chinese students in America stayed/have stayed in America and how their viewpoints changed would help define whether and how different societies affect Chinese students' view of advertisements on social media. 


\section{CHAPTER 7: Conclusion}

This research examined the social media diet of Chinese students in China and Chinese students in America, the different attitudes they had toward advertisements on social media, and why their attitudes were different through a web-based survey of Chinese students in these two countries. The survey results showed that Chinese students in America physically use more social media than Chinese students in China. Then, Chinese students in China hold more negative attitude toward social media advertising than Chinese students in America except when purchasing the advertised products and comparing their attitudes on social media with attitudes on traditional media. Chinese students in America hold a more positive attitude toward social media advertising than Chinese students in China, except noticing and understanding the fake or unethical social media advertising behaviors. Wherever Chinese students were in China or in America, the heavier social media users had stronger attitude toward advertisements on social media. Also, Chinese students in China considered advertisements on social media less trustworthy than Chinese students in America. 
Appendix 1: Screenshot of Renren-Chinese Version of Facebook

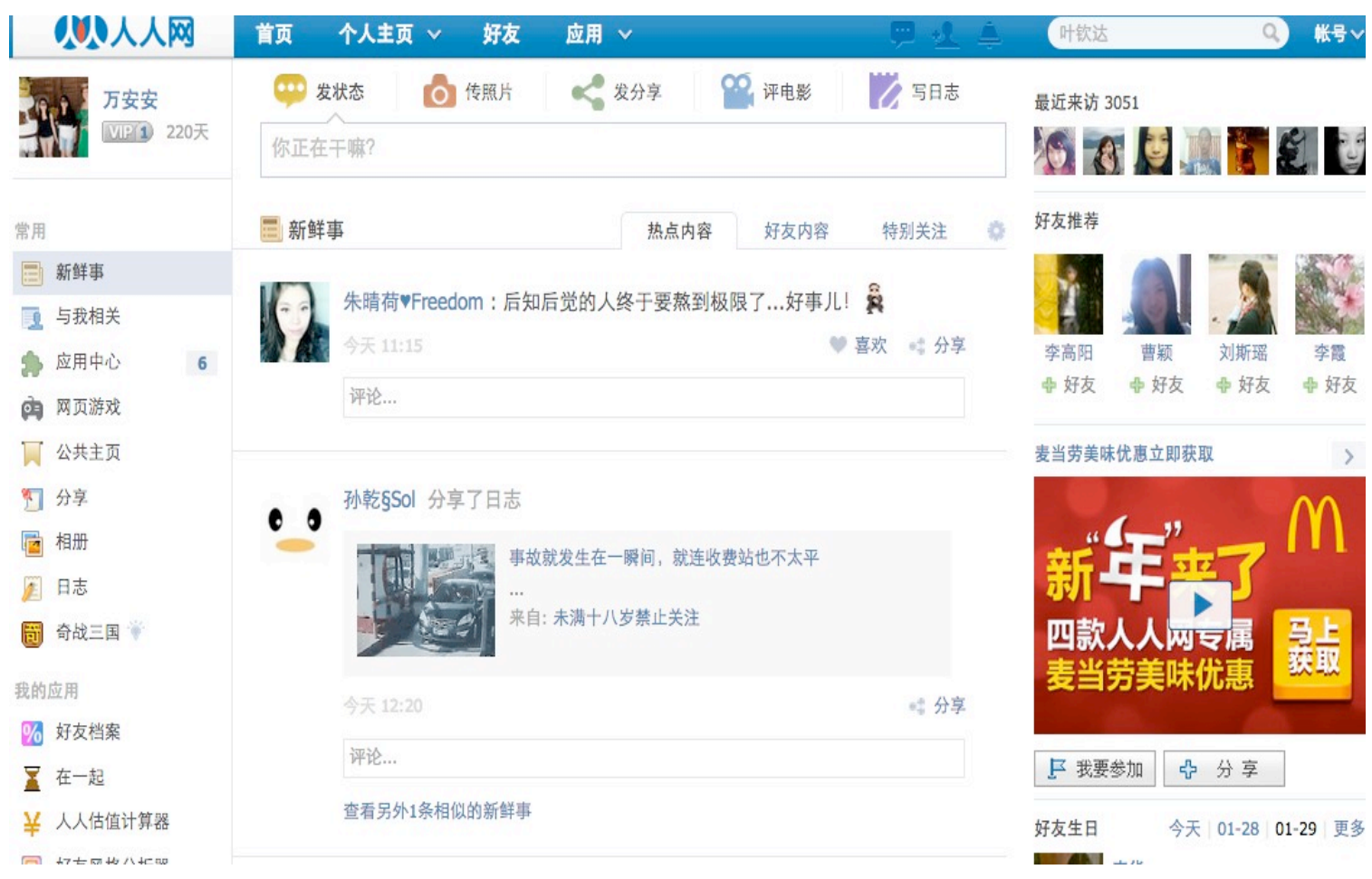


Appendix 2: Screenshot of Weibo-Chinese Version of Twitter

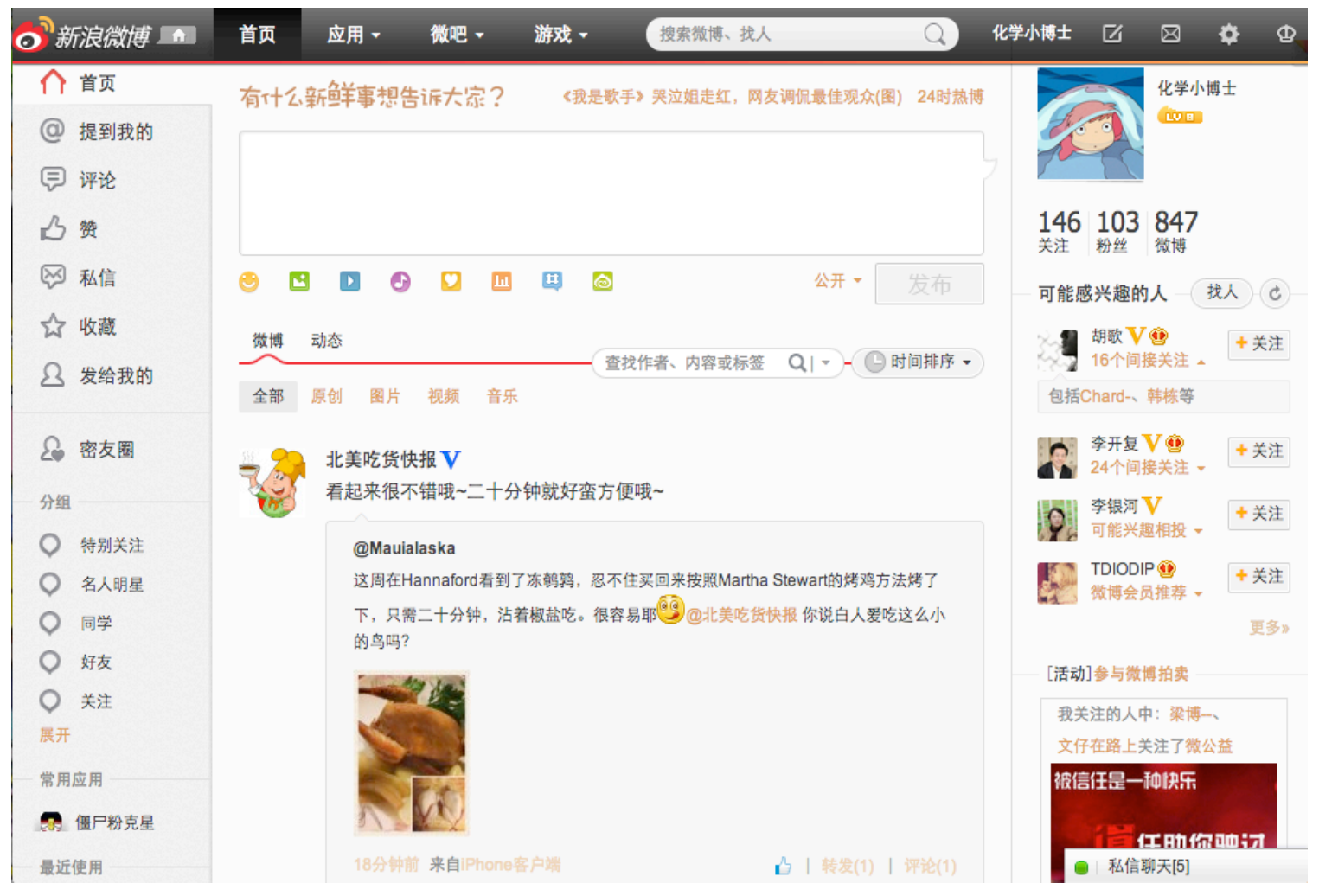


Appendix 3: Contact Message in English

\title{
WestVirginiaUniversity
}

\author{
Perley Isaac Reed School of Journalism
}

$\mathrm{Hi}$,

Please help me taking part in an important research study about how Chinese students in China and in America use social media and their attitude toward social media advertising. This research study is being conducted as part of my master's thesis for the Perley Isaac Reed School of Journalism at West Virginia University. Dr. Colistra is the faculty advisor for the project. West Virginia University's Institutional Review Board has acknowledgment of this study on file.

Your answers are private and confidential. I guarantee that your responses will not be identified with you personally. Only the faculty advisor and I will have the access to all the data. You may choose to quit the survey at any time you want.

Whether or not you choose to take part in this survey, please send the above survey link to another five Chinese students based on the following criteria.

(1) If you go/went to college in China, please send this survey link to five other Chinese students who go/went to college in China.

(2) If you go/went to college in America, please send this survey link to five other Chinese students who go/went to college in America.

\section{Again, you can access the survey at this link: \\ $<$ https://www.surveymonkey.com/s/ZFX688D $>$}

If you have any questions or concerns, please contact me at awan@mix.wvu.edu or (304) 777-0711.

Thank you for your participation and time!

Best,

Anan Wan

Graduate Student

Perley Isaac Reed School of Journalism

West Virginia University

Phone: 304-293-3505

Fax: 304-293-3072

journalism.wvu.edu/
Martin Hall

1511 University

PO Box 6010

Morgantown, WV 26506-6010
Equal Opportunity/Affirmative Action Institution 


\section{Appendix 4: Contact Message in Chinese \\ WestVirginiaUniversity \\ Perley Isaac Reed School of Journalism}

您好，

请帮助我参加这项关于中国大陆学生和在美国中国学生如何使用社交媒体以及他们对社交 媒体广告看法的研究。这想研究是我在西弗吉尼亚大学 Perley Isaac Reed 新闻学院研究生 毕业论文的一部分。Dr. Colistra 是我的论文指导老师。本研究已经由西弗吉尼亚大学科学 研究与伦理审理委员会批准并备案。

您的答案将被严格保密。我保证您的回答不会泄露你的身份。只有我本人和我的论文指导 老师能阅读使用所有信息。您可以任何时候退出此份问卷调查。

无论您是否参与此次研究, 请按照一下准则将这个问卷调查网址发给您的五个中国学生。

（1）如果您在中国上学的话, 请将它发给五个在中国上学的中国的学生。

（2）如果您在美国上学的话，请将它发给五个在美国上学的中国的学生。

请点此连接开始问卷调查: <https://www.surveymonkey.com/s/ZFX688D >

如果您有任何问题和顾虑的话, 请联系我, Email:awan@mix.wvu.edu 或者, 电话（304） 777-0711.

感谢您的参与和宝贵的时间！

万安安

Perley Isaac Reed 新闻学院

西弗吉尼亚大学

Phone: 304-293-3505

Fax: 304-293-3072

journalism.wvu.edu/

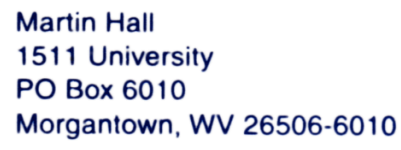

Equal Opportunity/Affirmative Action Institution 
Appendix 5: Consent Form in English

\section{WestVirginiaUniversity}

Perley Isaac Reed School of Journalism

\section{Consent for Web Survey}

By participating in this online survey, you agree to participant in a study being conducted by a master's student at West Virginia University. Your participation is voluntary and you may quit at any time. All precautions have been taken so there are no risks to your participation, unless you feel uncomfortable answering questions about yourself, how you use social media and your attitude toward social media advertising. If you have any question about this survey, you may contact the researcher, Anan Wan, at awan@mix.wvu.edu or (304) 777-0711. The faculty advisor and principal investigator for the research, Dr. Rita F. Colistra, may also be contacted at Rita.Colistra@,mail.wvu.edu or (304) 293-6793.

A committee that works to protect your rights and welfare reviews all research on human volunteers. West Virginia University's Institutional Review Board (IRB) has acknowledgement of this study on file. If you have questions or concerns about your rights as a research subject, you may contact, anonymously if you wish, the IRB at (304) 293-7073 or Johnathan.Young@mail.wvu.edu.

\section{What is the purpose of this study?}

The purpose of the research is to assess, through opinions of the Chinese students in China and Chinese students in America, the attitudes toward advertising on social media.

\section{How many people will take part in this study?}

If you decide to take part in this study, you will be one of the approximately 500 people asked to participant in this study.

\section{How long will your part in the survey last?}

The survey takes approximately six minutes to complete.

Phone: 304-293-3505

Fax: 304-293-3072

journalism.wvu.edu/
Martin Hall

1511 University

PO Box 6010

Morgantown, WV 26506-6010
Equal Opportunity/Alfirmative Action Institution 


\section{WestVirgniaUniversity}

\section{Perley Isaac Reed School of Journalism}

\section{How will your privacy be protected?}

Every effort will be made to ensure that your privacy and confidentiality will be protected. Your name and contact information will only be used to track who has or has not responded. Your name will not be used with any of the information obtained from this study or in any of the research reports. No information will be attributed to any individual participant or chapter. Results of each question will complied electronically by the Web survey program, and only I, Anan Wan, and my thesis chair (principal investigator) will have accesses to these data. I will avoid deductive disclosure by limiting my analysis to the overall data collected by respondents.

Thank you for your time and participation.

\section{Please click on the arrow below to begin the survey.}

Phone: 304-293-3505

Fax: 304-293-3072

journalism.wvu.edu/

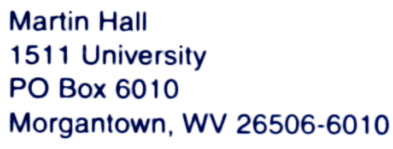

Equal Opportunity/Alfirmative Action Institution 
Appendix 6: Consent Form in Chinese

\section{WestVirgniaUniversity \\ Perley Isaac Reed School of Journalism}

\section{网络问卷调查同意书}

参与此网络问卷调查, 表明您同意参加由美国西弗吉尼亚大学研究生开展的研究。您 的参与是无偿的, 并且可以随时退出。预防措施已经采取, 所以参与此项研究您不会有任 何风险, 除非您对回答您的个人信息, 您使用社交媒体的习惯和您对社交媒体广告态度等 有关问题感到不适。如果您有任何问题, 请联系万安安, Email: awan@mix.wvu.edu, 电 话：（304）777-0711, 或者此项目导师（负责人）Dr. Rita F. Colistra, Email:

Rita.Colistra@mail.wvu.edu, 电话: （304）293-6793.

所有以志愿者为研究主体的项目都已通过以保障您的权利和福利的委员会的审核。西 弗吉尼亚大学科学研究及伦理审查委员会已经批准并备案此项研究。如果您对您作为研究 主体的权利有任何问题及顾虑, 您可以匿名联系西弗吉尼亚大学科学研究及伦理审查委员 会, 电话: (304) 293-7073, Email: Johnathan.Young@mail.wvu.edu.

\section{此项研究的目的是什么?}

此项研究的目的是通过中国大陆学生和在美国的中国学生的观点研究他们对于社交媒体广 告的态度。

\section{有多少人将参加此项研究?}

如果您同意参与此项研究, 您将成为 500 位问卷调查参与者之一。

此项研究将占用你多少时间？

此项问卷调查大概会占用您 6 分钟。 


\section{WestVirginiaUniversity}

\section{Perley Isaac Reed School of Journalism}

\section{你的隐私将如何被保护?}

您的隐私将被竭力保密。您的名字和联系方式只将被用于查询您是否回复此研究。您的名 字不会被用在任何从此项研究获取的信息之中和任何此研究的报告之中。所有信息将不会 归于任何个人或者组织。每一个问题的答案都将由网络调查程序自动汇总。只有研究负责 人, 万安安, 以及次研究导师 (负责人) 可使用这些数据。我将尽量限制对所有调查信息 的分析使用以避免推论泄露。

\section{谢谢您参与此项研究,请点击以下箭头开始问卷调查。}

Phone: 304-293-3505
Fax: 304-293-3072 journalism.wvu.edu/

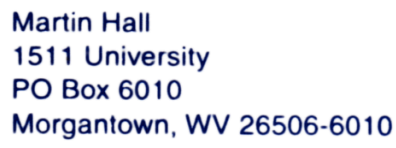

Equal Opportunity/Alfirmative Action Institution 
Appendix 7: Survey Questions in English

I would like to know a little about you. Please choose the answer that best applies. All the information you provided will be confidential.

1. Your gender is
A. Male
B. Female
C. Decline to answer

2. What is your age?
A. Younger than 18
B. $18-23$
C. 24-29
D. $30-35$
E. $36+$

3. What is the highest degree or level of school you have completed or are currently enrolled?
A. No schooling completed
B. Junior middle school graduate 

C. High school graduate
D. Some college credits
E. Bachelor's degree (including currently enrolled)
F. Master's degree (including currently enrolled)
G. Doctorate degree (including currently enrolled)

4. Did you get/are you pursuing any Bachelor's or higher degree in America?
A. Yes
B. No, all in China
C. Neither in America nor in China
D. Decline to answer
Please choose the one option that best describes your use of social media with the following statements. There are no right or wrong answers. Your answers will be confidential.

5. How often do you use Facebook or Twitter?

Never

1
Always 5

6. How many days do you use social networks per week (e.g., Renren, Weibo, Facebook, Twitter)?

A. 7 days per week 
B. 5 or 6 days per week

C. 3 or 4 days per week

D. 1 or 2 days per week

E.Not at all

7. How often do you check your social networks per day?
A. More than 20 times per day
B. 11-20 times per day
C. 6-10 times per day
D. 1-5 times per day

E.Not at all

8. How many years have you been using social networks?
A. 5 or more years
B. 3-4 years
C. 1-2 years
D. Less than 1 year
E.Not at all

Please choose the one option that best applies or that is your best estimate. There are no right or wrong answers. I am only interested in your viewpoints about social media and social media advertising.

9. Have you noticed the existence of advertisements on social media?
A. Yes 
B. No

C. Decline to answer

10. Have you noticed the existence of fake advertising on Chinese social media?
A. Yes
B. No
C. Decline to answer

11. Have you noticed the existence of fake advertising on American social media?
A. Yes
B. No
C. Decline to answer

12. Do you know what the "Water Army" is?
A. Yes
B. No
C. Not sure

13. Do you know what "Zombie Follower" is?
A. Yes
B. No
C. No sure 
14. Have you noticed the existence of "Water Army" or "Zombie Followers" on social media?
A. Yes
B. No
C. Decline to answer

Please choose the one option that most closely corresponds with your viewpoints, on a scale of 1 to 5. There are no right or wrong answers. I am only interested in your viewpoints about advertising in social media.

15. How often do you click the advertisements on social media for further information?

Never

Always

1

2

3

4

5

16. Do you think the advertisements on social media are annoying?

Never
2
3
4
Always
(2)

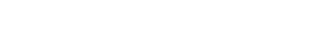
5

1

17. Do you trust the advertisement posted by the product's official social media account?

Never

Always

1

2

3

4

5

18. Do you trust the product reviews posted by your acquaintances? 
19. Do you trust the product reviews posted by non-official social media accounts?

Never

1
2
3
Always

4

20. Do you trust the contents of the advertisements on social media?

Never

1

21. How often do you purchase the product that is advertised on social media?

Never

Always

1 2 3 4

22. Do you think the advertisements on social media help you to make purchasing decisions?

Never

Always

1 2 3 4

23. Do you think the advertisements on social media (e.g., Weibo, Renren, Facebook, Twitter) affect your purchase more than the advertisements on other media (e.g., TV, newspaper, radio)? 
Always 
Thank you for your time and cooperation! If you have any additional comments, please type them in the box below, or contact me at awan@mix.wvu.edu or $<$ 001-304-777-0711 $>$.

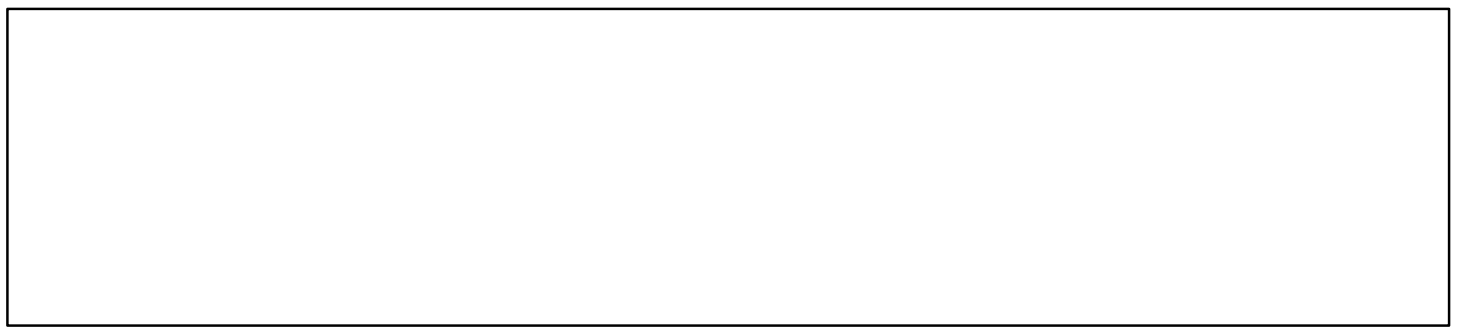


Appendix 8: Survey Questions in Chinese

\author{
问卷调查
}

为了了解您的个人信息, 请您回答下面几个问题。请选择你认为最 合适的选项。您提供的所有信息都将仅用于本次研究。

1. 您的性别是:
A. 男
B. 女
C. 拒绝回答

2. 您的年龄是?
A. 小于 18 岁
B. $18-23$
C. $24-29$
D. $30-35$
E. $36+$

3. 您的最高学历（包括在读）是什么?
A. 没有学历
B. 初中
C. 高中 

D. 本科肄业
E. 本科（包括在读）
F. 硕士（包括在读）
G. 博士（包括在读）

4. 您是否在美国获得过本科或者以上学历呢（包括在读）？
A. 是
B. 否, 一直在中国
C. 既不在中国, 也不在美国
D. 拒绝回答

请选择你认为最贴切形容您使用社交媒体习惯的选项。答案不分对 错。您提供的所有信息都将仅用于本次研究。

5. 您使用Facebook或者Twitter的频率是?

从不

总是

1

2

3

4

5

6. 您每周有几天使用社交网络（例如: 人人, 微博, Facebook, Twitter）?
A. 每周7天
B. 每周 5 天或者 6 天 

C. 每周 3 天或者 4 天
D. 每周 1 天或者 2 天
E. 从不

\section{7. 您每天查阅社交网络的频率是?}
A. 每天超过20次
B. 每天11-20次
C. 每天6-10次
D. 每天1-5次
E. 从不

8. 到目前为止, 您使用了多少年社交网络?
A. 5 年及更久
B. 3-4年
C. 1-2年
D. 不到 1 年
E. 从未用过 
请选择您认为最贴切描述你对社交媒体及社交媒体广告的观点的选 项。答案不分对错。您提供的所有信息都将仅用于本次研究。

9. 您是否曾经注意到社交媒体中广告的存在？
A. 是
B. 否
C. 拒绝回答

10. 您是否曾经注意到中国社交媒体中虚假广告的存在？
A. 是
B. 否
C. 拒绝回答

11. 您是否曾经注意到美国社交媒体中虚假广告的存在？
A. 是
B. 否
C. 拒绝回答

12. 您是否知道“水军”是什么?
A. 是
B. 否 
C. 不清楚

13. 您是否知道“僵尸粉”是什么?
A. 是
B. 否
C. 不清楚

14. 您是否曾经注意到社交媒体中 “水军” 或者 “僵尸粉” 的存在?
A. 是
B. 否
C. 拒绝回答

请选择从 1 到 5 , 五个不同程度中, 您认为最贴切反映你对社交媒 体中广告态度的选项。答案不分对错。您提供的所有信息都将仅用 于本次研究。

15. 您点击社交媒体中的广告以获取更多商品信息的频率是？

从不

总是

1

2

3

4

5

16. 您对社交媒体中的广告感到厌烦吗?

从不

总是 
17. 您相信社交媒体中官方账号发布的产品广告吗?

从不

总是

1

2

3

4

5

18. 您相信社交媒体中您的熟人发布对产品的评价吗?

从不

总是

1

2

3

4

5

19. 您相信社交媒体中非官方账号发布对产品的评价吗?

从不

总是

1

2

3

4

5

20. 您相信社交媒体广告的内容吗?

从不

总是

1

2

3

4

5

21. 您购买出现在社交媒体广告中的商品的频率是?

从不

总是

1

2

3

4

5 
22. 您认为社交媒体中的广告会影响您的购买行为吗?

从不

总是

1

2

3

4

23. 相对于传统媒体上的广告（例如: 电视, 报纸, 广播）, 您认为社交媒体（例

如: 人人, 微博, Facebook, Twitter）上的广告更能影响您的购买行为吗?

从不

总是

1

2

3

4

5

谢谢您的配合和宝贵的时间！如果您有其他评论, 请写在下面的输入框 中, 或者联系我, Email: awan@mix.wvu.edu, 电话: <001-304-777$0711>$. 
Appendix 9: IRB Approval Letter

\section{W. WestVhrginiaUniversity. \\ Office of Research Integrity and Compliance}

\section{Acknowledgement Letter - Exempt - Initial Protocol Review}

To:

From:

Date:

Subject:

Protocol Tracking\#:

Title:
Rita Colistra

WVU Office of Research Integrity and Compliance

03/07/2013

Acknowledgement Letter - Exempt - Initial Protocol Review

1303022261

How Do They Think Differently?: A Social Media Advertising Attitude Survey on Chinese Students in China and Chinese Students in America

The above-referenced study was reviewed by the West Virginia University Institutional Review Board (IRB) and was granted exemption in accordance with 45 CFR 46.101 (1-6).

All exemptions are only good for three years. If this research extends more than three years beyond the approved date, then the researcher will have to request another exemption. The documents listed below have been acknowledged for use in this study and are available in the Kuali Coeus system.

- This research study was granted an exemption because the Research involves educational tests, survey procedures, interview procedures or observation of public behavior and (i) information obtained is recorded in such a manner that human subjects cannot be identified, directly or through identifiers linked to the subjects; and (ii) any disclosure of the human subjects responses outside the research could not reasonably place the subjects at risk of criminal or civil liability or be damaging to the subject?s financial standing, employability, or reputation [45 CFR 46.101(2)]. All exemptions are only good for three years. If this research extends more than three years beyond the approved date, then the researcher will have to request another exemption. The following documents have been acknowledged for use in this study and are available in the WVU+kc system:

- Wan contact message.do

- Wan contact message-Chinese.doc

- Wan consent form.doc

- Wan consent form-Chinese.doc

- IRB Chinese H Lin.pdf

- Wan Survey Questions.doc

- Wan survey questions-Chinese.doc

If you have any questions, please contact the IRB at (304) 293-7073. 


\section{Appendix 10: Confirm Letter of Translation}

\section{WestVirginiaUniversity}

Eberly College of Arts and Sciences

March 2, 2013

To Whom It May Concern:

Ms. Anan Wan has asked me to verify the English translation of the following documents for her research project on how Chinese students use social media and their attitude toward social media advertising:

- Consent for Web Survey

- Cover letter/Contact for the Survey

- Survey Questions

Based on my review, the English translation of the materials is an honest representation of the Chinese versions, and that the survey questions do not contain anything deemed sensitive in nature.

Sincerely yours,

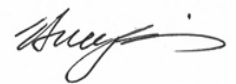

Hannah Lin, PhD.

Johnson Teaching Associate Professor

Chinese Studies Program Director

Email: $\underline{\text { Huey.Lin@mail.wvu.edu }}$

Phone: (304) 293-8328

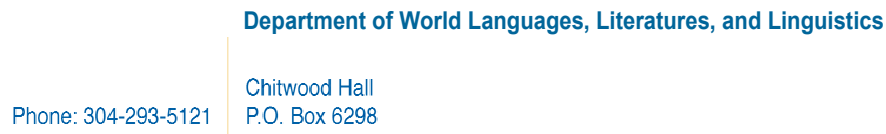

Fax: 304-293-7655 Morgantown, WV 26506-6298 Equal Opportunity/Affirmative Action Institution 


\section{Bibliography}

An, Y. (2012). Analysis on Social Media Research Data of Students in Shanghai. Advertisement Overview. 6(2), 85-89.

Bowman, N. D. (2012). How Demanding is Social Media: Understanding Social Media Diets as a Function of Perceived Costs and Benefits - a Rational Actor Perspective. West Virginia University.

Brown, B. B. (2012). The partnership between the American National Red Cross and Amateur Radio. West Virginia University.

Brown, J. D. (2000). Adolescents' Sexual Media Diets. Journal of Adolescent Health. $27(2), 35-40$.

Burns, Kelli S. (2008). The Misuse of Social Media: Reactions to and Important Lessons from a Blog Fiasco. Journal of New Communications Research. Vol. 3 Issue 1, p41$54,14 \mathrm{p}$

Cao, D. (2012). Characteristics of College Students' Internet Social Behaviors and Conducting Strategies. Education Theory Research. 5(2), 152-154.

Colistra, R. F. (2008). Reporter perceptions of influences on media content: A structural equation model of the agenda- and frame-building and agenda-cutting processes in the television industry. (Unpublished version of doctoral dissertation). University of North Carolina, Chapel Hill.

Fong, C. C. S. (2011) Strategic management accounting of social networking site service company in China, Journal of Technology Management in China, 6(2), 125-139.

Han, R., \& Ji, J. (2012). Survey on College Students' Attitude toward Rumors. Intelligence Practice \& Research. 23(1), 279-280. 
Hassid, J. (2008). Controlling the Chinese Media: An Uncertain Business. Asian Survey, 48(3), 414-430.

Healy, S. (2007). The Great Firewall of China. Social Education, 71(3), 158-163. Internet Water Army. (N. D.). Retrieved November 15, 2012 from Wikipedia: http://en.wikipedia.org/wiki/Internet_Water_Army.

Johnson, C. A. (2012). The Information Diet: A Case for Conscious Consumption. Sebastopol, CA: O'Reilly Media.

Kellogg, S., McHugh, P., Bell, K., Schluger, J., Schluger, R., LaForge, K., Ho, A., \& Kreek, M. (2003). The Kreek-McHugh-Schluger-Kellogg Scale: A New, Rapid Method for Quantifying Substance Abuse and Its Possible Applications. Drug \& Alcohol Dependence. 69 (2003), 137-150.

La Ferle, C., Edwards, S. M., \& Lee, W. (2008). Culture, Attitudes, and Media Patterns in China, Taiwan, and the U.S.: Balancing Standardization and Localization Decisions. Journal Of Global Marketing, 21(3), 191-205.

Ouyang, W. (2012). "Renren" Loves "Weibo"- Introspection on Chinese Social Networks. News Dissemination. 9(2), 83-84.

Roberts, D. F. (2000). Media and Youth: Access, Exposure, and Privatization. Journal of Adolescent Health. 27(2), 8-14.

Shim, S. W. (2011). A Study on the Effects and Motives of College Students Using Social Media on Advertisement Usage Between Korea and China. 2011 China \& Korea International Advertising Seminar.

Smith, Tom. (2009). The Social Media Revolution. International Journal of Market Research. Vol. 51, Issue 4, p559-561, 3p. 
Viner, N. L. (2007). The Global Online Freedom Act: Can U.S. Internet Companies Scale the Great Chinese Firewall at the Gates of the Chinese Century? Iowa Law Review, 93(1), 361-391.

Xiao, H. (2011). "Renren Effects"- Evaluation Standards of SNS Advertising. Interactive Marketing. 1(2), 104-105.

Yang, H. (2009). Development and Strategies of Viral Advertising in Social Media: using "Renren" as example. Macro Management. 11(2), 27-28.

Zhang, Y. (2011). "Zombies and "Phantom" Fans Haunt Online Statistics". Retrieved from http://news.xinhuanet.com/english2010/indepth/2011-11/22/c 131261763.htm.

Zhao, H., \& Wu, Y. (2012). Development and Conducting Strategies of Audience Opinions Manipulated by “Internet Water Army”. The Press. 11(2), 38-41.

Zhou, S. \& Sloan, WM. D. (2011). Research Methods in Communication. Northport, AL: Vision Press.

Zong, S. (2010). Don't Look Down upon the Internet "Water Army". Liao Wang News Weekly. 